logy will find this book of value both for reference and as a useful additional companion to more systematic works during their training. Its scope is deliberately limited so that it is perhaps more suitable for library or departmental use than for one's personal bookshelf, particularly at $£ 7.00$ for eighty-five pages of text.

\section{Progress in Hematology Vol. 7}

Edited by E. M. Brown and C. V. Moore. Pp. 416, illustrated. London: William Heinemann Medical Books, 1972. £10.25.

This volume contains eleven chapters which deal with various growing points in haematology. The topics chosen range as widely as from instrumentation and automation in haematology (Dr G. Brittin and Dr G. Brecher) to food iron absorption (Dr M. Layrisse and Dr C. Martinez-Torres), and from the plasma kallikrein-kinin system (Dr R. W. Colman, Dr G. J. D. Girey, Dr R. Zacest and Dr R. C. Talamo) to red cell metabolites, haemoglobin and the oxygen dissociation curve (Dr F. A. Oski and Dr A. J. Gottlieb). In general, the present volume maintains the high standard of its predecessors. An outstanding chapter, written by Dr J. M. White and Professor J. V. Dacie, reviews the clinical and molecular features of the unstable haemoglobins. Some idea of the rapid advances that are now taking place in this, as in other areas of haematology, however, is illustrated by the fact that at least twenty new unstable haemoglobins have been recognized since this review of the first thirty such haemoglobins to be documented was completed. The longest chapters are comprehensive and exhaustively referenced reviews of the leukaemias by Dr D. A. G. Galton and Dr A.S. D. Spiers and of platelet function in health and disease by Dr J. Hirsh and Dr J. C. G. Doery; the shortest and, in some instances, easier to read, concern disorders of phagocytic cell function (Dr D. G. Nathan and Dr R. L. Boehner), surface cell receptors (Dr S. Kornfeld and Dr R. Kornfeld) and the haemopoietic action of androstanes (Dr L. Sanchez-Medal). An interesting chapter on erythrocytes in blood rheology (Dr P. L. LaCelle and Dr R. I. Weed) completes the volume.

This book is probably too expensive for many individuals to buy their own copy. Nevertheless, it provides a relatively painless way of learning about many of the recent advances in haematology and it is to be hoped, therefore, that it willo be widely read.

\section{The Platelets}

Edited by K. M. Brinkhous, R. W. Shermer and F. K. Mostofi. Pp. 420, illustrated. Edinburgh and London: Churchill Livingstone, 1972. $£ 12.00$.

This is a collection of twenty-six chapters, each of which $\bar{\sigma}$ is an expansion of a lecture given at the 58th annual meeting $\overline{\bar{D}}$ of the International Academy of Pathology. The contributors $\widetilde{\Phi}_{\mathbb{D}}$ are, with one exception, from North America and they deale with most of the conceivable aspects of the subject including megakaryocytic morphology and function, platelet structure, function, survival, transfusion and the diseases in which the $\vec{O}$ platelets are qualitatively or quantitatively abnormal. Thanks to application of new techniques of electron microscopy, $\vec{\omega}$ biochemistry and immunology, knowledge of the platelet now approaches that of the red cell and, indeed, as this volume shows, there are remarkable similarities between the 3 production and life-span of these two non-nucleated, circulating particles and the diseases that affect them. The $c$ general standard of the articles is high and each is wellor illustrated, easy to read, and supported by references which are numerous and include articles published as recently as $\infty$
1970 .

The academic will appreciate the advantages of multi-음 authorship, since what is taken for granted by one expert may be questioned by another. For instance, Harker assumes $\vec{c}$ that megakaryocyte volume parallels the number of nuclei and that DNA replication in these cells is necessarily followed $\underset{\Sigma}{\check{C}}$ by endomitosis, whereas Ebbe points out that these assumptions may not be justified on the present available experimental data. On the other hand, the busy laboratory worket $\vec{\varphi}$ and clinician will find much of immediate practical value such as the excellent chapter by Aster on platelet transfusion which provides a valuable guide to both the laboratory affif clinical aspects of this subject.

Unfortunately, this volume is expensive and, with the recent plethora of haematological texts, will probably only $\bar{O}$ be bought by libraries or haematologists with a special interest in platelets. It is to be hoped, however, that a wider $\mathbb{D}$ audience will use this book as a means of becoming acquainted with the vast knowledge of the platelet that has recently
accumulated. 